candidate - a personable 39-year-old physicist called Daniel Thoulouze - is also likely to be the recommendation of the relevant section of the Comité National, so there may be no conflict. But the CNRS directorate is put in an awkward position whatever the result. If it selects Thoulouze, it will appear to approve of the grass-roots election of laboratory directors - which it wants to avoid. Yet if it selects another, it will appear to confirm the fears of the more radical scientists and the strong trades union movement in French science that, despite a socialist government, the selection of laboratory directors - who have great power over their laboratories will remain closed and centralized.

In the event, the CNRS may be forced to ask Tournier to continue. The new CNRS director-general, Jean-Jacques Payan, is not against elections in principle; but he says they should be undertaken only "in a very precise framework", meaning that the electorate should be appropriate to the category of post. But Payan is under great pressure from the grass roots, the technicians and the younger researchers, for a more democratic way of appointing directors, and he will certainly have to give in to some extent. As Tournier himself said this week, the question is whether the CNRS is forced into a system where directors must conform to majority opinion in a laboratory, or a system where the directors can be independent, but must subsequently seek to bring the whole laboratory behind them.

Meanwhile the unions of Grenoble, which have enjoyed a large degree of democracy (or at least, consultation), since 1968 , are determined to be "serious" about the election. The candidates were grilled in debates, and their scientific and general laboratory policy examined, they said. The unions' objective is that the laboratory should continue to do good science, and they insist that that requires the director to have good relations with his staff, down to the lowest technician.

And to some extent, this policy is reflected at the Ministry of Research and Technology in Paris, which gave Payan his job at the CNRS. The strong feeling there is that science is more and more a collective exercise - and that democracy and efficiency go together. But on the other hand, they also feel at the ministry that too much democracy leads to "turbulence", a position which would seem to be close to Payan's own (which is perhaps not surprising, for the minister for science, Jean-Pierre Chevènement, and Payan have been close colleagues for a decade.)

In the end, the issue is going to be how far Chevènement is prepared to travel with the unions - and particularly the communist-affiliate CGT, which is strong at Grenoble. The CGT secretary here said last week that he and his union were watching and waiting. And if Chevènement does not come up to their expectations, he promises a struggle.

\section{What price IIASA? Washington}

The Vienna-based International Institute for Applied Systems Analysis (IIASA) has now been informed officially that the United States will be withdrawing its support for the institute from the beginning of 1983 (see Nature 3 December, p.390). This gives IIASA some breathing space in which to seek ways of keeping the United States involved - even if its contribution is severely reduced.

At present the United States and the Soviet Union together provide about half of IIASA's $\$ 10$ million annual budget, and the IIASA council is now looking at ways to reassess the dues from each of the member nations. At present the United States's $\$ 2.5$ million contribution comes from the National Science Foundation and is channelled through the National Academy of Sciences, and one possibility is that the money might be raised from other federal agencies. Private foundations are also being approached but so far all offers for support have been well below current levels.

Whether the United States will come back remains an open question. Founded in the early 1970 s as a symbol of detente, IIASA has provided a useful window for both East and West on economic and social conditions on the other side - for example information about energy resources. But the institute has failed to stem doubts about the true academic value of its work.

David Dickson

\section{Pakistan's space ambitions}

\section{A military option?}

\section{Bangalore}

Pakistan looks set to embark upon an ambitious programme of space research with clear hints that the spur is the prospect of military applications in the long term. Dr Salim Mahamood, chairman of Pakistan's Space and Upper Atmospheric Research Commission (SUPARCO), while unveiling the details of a 10-year national space programme in Islamabad recently, said that Pakistan did not want to be left behind in the space race, and that his country is studying in detail the configuration of a satellite which "can serve strategic purposes by taking pictures of military installations, army movements and acting as control, command and communication bases".

The setting up of SUPARCO earlier this year, with President Zia at its head, is said to have given fresh impetus to the hitherto slow-moving Pakistani space programme which is currently concerned mainly with launching sounding rockets from a base on the qutskirts of Karachi. Dr Mahamood claims that Pakistan is on the way to developing a communications satellite that "would be launched with the aid of either a European or an American rocket".

Since the successful flight test of India's SLV-3 rocket in July 1980, there have been fears in Pakistan that India might use experience gained with SLV-3 to build a strategic missile. Indeed, in November 1979 an Indian parliamentary committee was told that within six months of a political decision, SLV-3 could be modified into a medium-range ballistic missile. But the Indian Space Department stresses that military objectives are beyond the purview of the Indian space programme which is directed at "harnessing space for socio-economic development".

There is concern too that with the launch of the Bhaskara II satellite, India is developing the ability not only to survey the land for natural resources but also to carry out military surveillance over Pakistan.

Dr Mahamood claims that over the next five years, Pakistan will attempt to test a space launch vehicle of its own. The controversial deal between Pakistan and the West German private enterprise space agency OTRAG seems to be in obeyance. It is claimed that Colonel Gadaffi, OTRAG's host in Libya, had contacted Pakistan with an offer of OTRAG's technology.

How true is the rumour of a link between OTRAG and Pakistan is not known but some strategic analysts say that OTRAG could provide about 2,000 qualified space technologists badly needed to bolster Pakistan's space research efforts.

Meanwhile, Pakistan is negotiating with the US National Aeronautics and Space Administration for the setting up of a $\$ 10$ million ground station near Islamabad to receive earth resources data from the Landsat remote sensing satellite.

\section{B. Radhakrishna Rao}

\section{India's space programme}

\section{Now for real}

\section{New Delhi}

India entered a new phase in its development of a series of satellites for remotesensing applications with the successful launching of its experimental satellite Bhaskara II, into a circular Earth orbit from the Soviet Union on 20 November. India's space programme for the 1980s includes as one of its two chief goals a major survey of natural resources. The other task is the development of spacebased communications system. The first operational satellite, the National Satellite 1 A will be launched in April 1982.

The 440-kilogramme Bhaskara II is an improved version of Bhaskara I, which went out of action, after 26 months, in August. Modifications to the camera system should eliminate the "corona discharge" which caused the breakdown of one of the two television cameras aboard Bhaskar I for a few months. And an extra 